УДК 378.016

DOI:

Віктор Лиходід, кандидат технічних наук, доиент кафедри садово-паркового господарства

Комунальний вищий навчальний заклад

“Хортицька національна навчально-реабілітаційна академія” Запорізької обласної ради

\title{
ДИСЦИПЛІНА “ОСНОВИ ФАХОВОЇ ПІДГОТОВКИ” У ПРОФЕСІЙНОМУ СТАНОВЛЕННІ ФАХІВЦІВ САДОВО-ПАРКОВОГО ГОСПОДАРСТВА ХОРТИЦЬКОЇ НАЦІОНАЛЬНОЇ АКАДЕМЇ̈
}

У статті розглянуто дисципліну “Основи фахової підготовки” у професійному становленні майбутніх фахівиів садово-паркового господарства у межах Хортицької начіональної академії (ХНА), теоретично обтрунтовано ї̈ ефективність та доцільність застосування як дієвого засобу, що розвиває позитивне ставлення до обраної професії та сприяє гармонійному входженню у навчальний прочес. Автор зазначає, що вивчення даної дисиипліни формує уявлення про права та обов 'язки студентів у навчальному проиесі закладу вищої освіти, щзо має позитивний вплив на формування професійної компетентності студентів садовопаркового господарства та виводить підготовку фахівців даної галузі на нову площину сучасної освіти.

Ключові слова: фахівиі садово-паркового господарства; професійна компетентність; заклад вищої освіти; соціальна адаптація; фахова підготовка; мотивачія.

Jim. 5.

Viktor Lykhodid, Ph.D.(Technical Sciences), Associate Professor of the Garden and Park Design Department Municipal Higher Educational Institution "Khortytsya National Educational and Rehabilitation Academy" of the Regional City Council of Zaporizhzhya

\section{COURSE "BASICS OF PROFESSIONAL TRAINING" IN TRAINING THE SPECIALISTS IN GARDEN AND PARK DESIGN AT THE KHORTYTSYA NATIONAL ACADEMY}

The article analyzes the course "Basics of professional training" in preparing the specialists of garden and park design at the Khortytsya National Academy (KNA). The article describes a thematic plan of the course, including a goal and tasks, justifies their logical structure and effectiveness as an efficient way, which develops a positive attitude towards a selected profession and assists in a harmonious integration into an educational process (social adaptation of the first-year students). The article emphasizes that the course is the basis in preparing the garden and park design specialists and forming their professional competence.

The author indicates that taking the course forms the understanding of the rights and obligations of the students in the educational process of the KNA, teaching students to manage their time effectively, makes the students familiar with the specific nature of work of the KNA, forms of training activity, main documents, which regulate the studying at the academy; introduces the history of the KNA and the faculty, the history of the department of garden and park design, introduces the research papers of the scientists, who have developed this field; introduces the knowledge from the history and development of garden and park design of Ukraine, prospects for its development in the modern context; forms the motivation to study and master the selected profession; teaches the students to determine goals and tasks; gives basic knowledge of fundamental sciences of landscaping. It is indicated in the article that the course "Basics of professional training" is based on general didactic principles: humanization, scientific character of the content of teaching and teaching methods, practical orientation of education, demonstrativeness, individualization, added with the principles of a positive emotional charging of the educational process, motivation towards a creative uniqueness, a creative combination in accordance with the specific character of training the specialists of garden and park design.

The author theoretically justifies that the course "Basics of professional training" is one of important ways of training the specialists of garden and park design and enables a harmonious introduction of students to the selected specialty (a specialist of garden and park design), creates conditions for a rational motivation of a personality towards studying.

Keywords: specialists in garden and park design; professional competence; higher educational institution; social adaptation; professional training.

$\Pi$

остановка проблеми. У XXI столітті постала гостра необхідність у компетентних фахівцях садово- паркового господарства, що обумовлено зростанням населення планети, розбудовою промисловості та збільшенням площ землі, які 


\section{ДИСЦИПЛІНА “ОСНОВИФАХОВОЇ ПІДГОТОВКИ” У ПРОФЕСІЙНОМУ СТАНОВЛЕННІ ФАХІВЦІВ САДОВО-ПАРКОВОГО ГОСПОДАРСТВА ХОРТИЦЬКОӤ НАЦІОНАЛЬНОЙ АКАДЕМІЇ}

використовуються у сільському господарстві; фахівцях, на підготовку яких витрачався $б$ найменший час та залучення професійних кадрів 3 максимально можливим результатом спеціалістом високого рівня. Такі вимоги сучасності сприяють активному розвитку та вдосконаленню системи освіти. Вітчизняні та закордонні науковці закладів вищої освіти знаходяться у стані переосмислення структури навчання, уточнення його суті, віднаходження ефективних методів та засобів для продуктивності та актуальності освіти, метою якої стає формування висококомпетентного фахівця садово-паркового господарства. Для досягнення визначених результатів ведуться дослідження 3 метою конкретизації технологій підготовки таких фахівців, що зможе дати гарантований результат навчання. Дане питання не оминуло підготовку фахівців садово-паркового господарства, де технологічний та суспільний розвиток вимагає постійного оновлення навчального матеріалу. Постає проблема, коли студенти першого курсу не засвоюють частини знань, тому що проходять адаптаційний період переходу від старшої школи до структури навчання у закладі вищої освіти, що пов'язано з великим емоційним напруженням, через це спостерігається зниження мотивації до навчання. Дисципліна “Основи фахової підготовки” створена спеціально для першокурсників та, як засіб комфортного входження у професію, дає змогу студентам усвідомити суть процесу підготовки фахівця садово-паркового господарства, $€$ основою успішного формування їх професійної компетентності.

Аналіз останніх досліджень і публікацій. Поняття “компетентність”, структуру професійної компетентності фахівців певних галузей досліджували зарубіжні (В. Байденко, В. Болотов, Ф. Вайнверт, А. Вербицький, Т. Добудько, В. Долл, Ю. Ємельянов, Е. Зеєр, І. Зимня, В. Краєвський, Н. Кузміна, Дж. Кулаген, А. Маркова, А. Новиков, Ж. Перре, В. Сериков, Дж. Равен, М. Роменвілль, М. Сміт, Ю. Татур, А. Хуторський, А. Чошанов, С. Шишов, Е. Шорт) та вітчизняні науковці (Н. Бібік, Л. Ващенко, С. Гончаренко, О. Гура, О. Локшина, В. Маслов, О. Пометун, Л. Хоружа, А. Хуторський).

Теоретичною основою дослідження стали роботи із теорії психологічної та соціальнопсихологічної адаптації людини (К. АбульхановаСлавська, Л. Анциферова, Г. Балл, Т. Дудкевич, I. Котова, О. Маслоу, О. Налчаджян, Г. Олпорт, Б. Паригін, О. Реан, К. Роджерс, Є. Шиянов та ін.).

Метою статті $\epsilon$ аналіз та теоретичне обгрунтування доцільності вивчення дисципліни
“Основи фахової підготовки” як засобу успішної соціальної адаптації та раціональної мотивації до навчання студентів закладу вищої освіти, яка стає основою у формуванні професійної компетентності майбутніх фахівців садово-паркового господарства.

Виклад основного матеріалу. Проблема підготовки висококомпетентних фахівців $\epsilon$ предметом дослідження науковців останніх десятиліть, таке положення стосується і фахівців садово-паркового господарства. Зростання населення, розвиток індустрії та сільського господарства призводить до знищення природних фондів України, нераціонального їх використання. Такі обставини вимагають підготовки компетентних фахівців садово-паркового господарства, що сприятимуть збереженню природи та створенню рукотворних іiї куточків, озелененню міст. Студентам першого курсу складно адаптуватися до нових умов навчання, це призводить до зниження мотивації та впливає на засвоєння навчального матеріалу, який у перший рік навчання складає основу майбутньої професії. Виникає проблема мотивації студента до навчання та опанування обраної професії на високому рівні (компетентний фахівець).

Практична професійна діяльність компетентного фахівця садово-паркового господарства передбачає:

- організацію та проведення робіт, пов'язаних з садово-парковим господарством і будівництвом;

- розробку, розрахунки авторських дизайнерських проектів садово-паркового господарства та їх реалізацію;

- виконання планування та озеленення територій різного призначення - робота 3 індивідуальними проектами та проектами міського масштабу;

- вирощування та догляд за деревами, кущами, квітковими рослинами (відкритого та закритого типу грунту) для подальшого їх використання у власних та колективних проектах;

- проведення комплексу робіт (аналітичні роботи) з рослинами на об'єкті озеленення, метою яких $є$ збір інформації для подальших робіт;

- економічні розрахунки для обгрунтування проектних рішень різних типів;

- налагоджування зв'язку із садово-парковими господарствами регіону та України для спільних проектів.

Мотивація студентів першого курсу тісно пов'язана із спрямованістю особистості, зумовлюе останню. Водночас їх слід розмежовувати. У характеристиці спрямованості головне - оцінка активності особистості, ï 


\section{ДИСЦИПЛІНА “ОСНОВИФАХОВОЇ ПІДГОТОВКИ” У ПРОФЕСІЙНОМУ СТАНОВЛЕННІ ФАХІВЦІВ САДОВО-ПАРКОВОГО ГОСПОДАРСТВА ХОРТИЦЬКОӤНАЦІОНАЛЬНӦ̈ АКАДЕМІЇ}

життєвої позиції щодо цінності для суспільства, а у визначенні мотивації - зміст і динаміка (напруженість, швидкість перебігу, інтенсивність) системи спонукань до діяльності $[2,88]$. У нашому дослідженні - це мотивації до навчання, що $\epsilon$ основою формування професійної компетентності, здобуття обраної спеціальності - фахівця садово-паркового господарства.

Великий тлумачний словник надає таке трактування поняття “мотивація":

- сукупність мотивів, доказів для обгрунтування чогось; мотивування;

- доведення необхідності скоєння певних вчинків;

- заохочення студентів (учнів) до вивчення певного предмета, дисципліни, пояснення необхідності навчання [1, 629].

Таким чином, мотивація $\epsilon$ важливою складовою навчання фахівця садово-паркового господарства. Дисципліна “Основи фахової підготовки” стає засобом раціональної мотивації студентів у їх професійному становленні.

Наступною складовою $є$ соціальна адаптація студентів у закладі вищої освіти. Соціальна адаптація - вид взаємодії особистості або соціальної групи із соціальним середовищем, в процесі якого узгоджуються вимоги й очікування його учасників. Найважливішим компонентом адаптації є узгодження самооцінки і прагнень суб'єкта 3 його можливостями, 3 реальністю соціального середовища, що містить як реальний рівень, так і потенційні тенденції розвитку середовища й суб'єкта організмів до умов існування і звикання до них $[3,11]$. Отже, структура дисципліни побудована таким чином, щоб забезпечити комфортну соціальну адаптацію студентів першого року навчання, де вони засвоюють всі види навчальної діяльності, іiі практичні прояви, вивчають макросередовище (заклад вищої освіти), його структурні складові та систему функціювання, мікросередовище структура та логіка навчального процесу фахівця садово-паркового господарства.

Головним елементом у всьому навчальному процесі фахівців садово-паркового господарства $\epsilon$ кінцевий результат - сформованість професійної компетентності, конкурентоспроможний фахівець здатний навчатися впродовж життя. Міжнародна рада із стандартів навчання, досягнень та освіти (International Board of Standards for Training, Performance and Instruction (IBSTPI) професійну компетентність фахівця розкриває як набір специфічних знань, навичок і відносин, які дозволяють людині ефективно виконувати професійну діяльність відповідно до встановлених стандартів [5].
Науковець А.В. Хуторський зазначає, що професійна компетентність - це наявність у людини певних компетенцій, що включає особисте ставлення до неї та предмету діяльності [4].

Таким чином, професійна компетентність фахівців садово-паркового господарства становить сукупність необхідних фахових знань, умінь та навичок, здатність до одночасного комбінованого динамічного використання теоретико-практичних знань у професійній діяльності; вміння знаходити необхідну інформацію; розвинута здатність до креативного мислення, проектної діяльності та навчання впродовж життя.

Дисципліна “Основи фахової підготовки” грунтується на загальнодидактичних принципах: гуманізації, науковості змісту і методів навчання, практичній спрямованості навчання, наочності, індивідуалізації, які доповнено згідно специфіки підготовки фахівців садово-паркового господарства принципами позитивної емоційної насиченості навчального процесу, мотивацією до творчої унікальності, комбінаторності.

Розглянемо більш детально мету, структуру тему та завдання дисципліни, що відповідають вимогам доцільної мотивації студентів до навчання, їх адаптації та сприяють формуванню професійної компетентності.

Мета дисципліни: ознайомити студентів із специфікою спеціальності фахівця садовопаркового господарства, його призначенням та роллю у галузі садово-паркового господарства України; надати необхідні знання щодо структури та організації навчального процесу, роботи підрозділів, внутрішнього розпорядку Хортицької національної академії; сформувати базові навички роботи з теоретичними матеріалами, пошуком та класифікацією інформації; надати знання 3 основних етапів розвитку садово-паркового господарства у історичній ретроспективі та сучасній Україні.

Теми дисципліни (модуль 1) розроблені таким чином, щоб допомогти студентам першого курсу швидко адаптуватись до умов закладу вищої освіти (ХНА):

- Тема № 1. Вступ. Історія розвитку ХНА. (Основні складові структури ХНА, факультету мистецтва та дизайну, кафедри садово-паркового господарства. Сучасний розвиток садовопаркового господарства у регіоні);

- Тема № 2. Базові правила внутрішнього розпорядку в ХНА. (Структура навчання в ХНА. Опис графіку навчального процесу ХHA. Положення про заліки та екзамени в ХНА. Профілюючі та допоміжні дисципліни у підготовці 


\section{ДИСЦИПЛІНА “ОСНОВИ ФАХОВОЇ ПІДГОТОВКИ” У ПРОФЕСЙНОМУ СТАНОВЛЕННІ ФАХІВЦІВ САДОВО-ПАРКОВОГО ГОСПОДАРСТВА ХОРТИЦЬКОЇНАЦІОНАЛЬНОЇ АКАДЕМІЇ}

фахівців садово-паркового господарства (бакалавр);

- Тема № 3. Організація навчального процесу у ХНА. (Розклад занять, заняття за “чисельником" та “знаменником”. Форми навчальної роботи. Права та обов’язки студентів. Навчальні корпуси та лабораторії ХНА);

- Тема № 4. Інформаційна культура студента. (Правила роботи з книгою, реферування та робота 3 навчальною літературою. Конспектування лекцій. Робота над курсовими роботами. Наукова робота. Організація та основні положення самостійної роботи. Планування часу. Робота 3 бібліотечними каталогами для пошуку необхідної літератури).

Друга частина (модуль 2) присвячена особливостям спеціальності фахівця садовопаркового господарства від зародження до сучасних тенденцій розвитку в Україні:

- Тема № 5. Кваліфікаційні вимоги до підготовки фахівця садово-паркового господарства (Професіограма фахівця садовопаркового господарства);

- Тема № 6. Історія, характеристики та організаційна структура садово-паркового господарства України. (Історія виникнення та розвитку садово-паркового господарства України. Загальна характеристика парків України. Організаційна структура парків України);

- Тема № 7. Садово-паркове господарство в Україні у XXI столітті. (Роль і місце галузі в народному господарстві України. Тенденції розвитку українського садово-паркового господарства України).

Загальні завдання дисципліни відповідають вимогам кваліфікаційної характеристики фахівця садово-паркового господарства, розгорнуто та логічно студентам викладається навчальний матеріал з метою усвідомлення ними, що знання, вміння та навички, які вони повинні отримати за період навчання із обраної спеціальності, є необхідними для їх професійного становлення та успішної професійної реалізації як компетентних фахівців.

Завдання дисципліни полягають у вивченні прав і обов'язків студентів ХНА, навчанні студентів раціонального планування власного часу, знайомстві із специфікою роботи ХНА, формами навчальної роботи, основними документами, які регламентують навчання у академіі; ознайомленні студентів з історією ХНА та факультету, історією кафедри садово-паркового господарства, знайомством $з$ роботами видатних вчених, що розвивали дану галузь; вивченні історії та розвитку садово-паркового господарства України, перспектив його розвитку в сучасності; формуванні мотивації до навчання та здобуття обраної професії; створенні підгрунтя для формування професійної компетентності; навчанні студентів визначати цілі і завдання; засвоєнні базових знань фундаментальних наук 3 ландшафтного дизайну.

Отже, результатом вивчення дисципліни “Основи фахової підготовки” $є$ студент, що розуміє суть обраної професії, має повне уявлення про навчальний процес академії, власні права та обов'язки, вміє знаходити необхідну інформацію та фільтрувати іiі за рівнями достовірності та якості, оформляти їі відповідно завдань, йому притаманний високий рівень мотивації до навчання; студент усвідомлює структуру, етапи та цілі навчального процесу в загальному розумінні підготовки фахівця садово-паркового господарства i окремих предметів, вміє раціонально розраховувати власний час для досягнення даних цілей.

Таким чином, нами було теоретично обгрунтовано доцільність вивчення дисципліни “Основи фахової підготовки” як засобу, що складає основу ефективного формування професійної компетентності майбутніх фахівців садово-паркового господарства та їх успішної соціальної адаптації у закладі вищої освіти.

\section{ЛІТЕРАТУРА}

1. Великий тлумачний словник сучасної української мови (з дод. і допов.) / Уклад, і голов, ред. В. Т. Бусел.К.:ВТФ “Перун”, 2005. - 1728 с.

2. Дугкевич Т. В. Загальна психологія. Теоретичний курс. [текст] навч. посіб. / Т. В. Дуткевич. - К.: Центр учбової літератури, 2016. - 388 с.

3. Термінологічний словник з основ підготовки наукових та науково-педаго-гічних кадрів післядипломної педагогічної освіти / авт. кол.: Є. Р. Чернишова, Н.В.Гузій, В. П. Ляхоцький [та ін.]; за наук. ред. Є. Р. Чернишової; Держ. вищ. навч. заклад "УН-т менедж. освіти". - К.: ДВНЗ “Університет менеджменту освіти”, 2014. -230 с

4. Хуторський А. В. Ключевые компетенции и образовательные стандарты: Доклад на Отделении философии образотворческой и теоретической педагогики. РАО 23 апреля 2002 г. [Электронный ресурс] / А. В. Хуторской - Центр “Эйдос”. - Режим доступу до ресурсу: http://www.eidos.ru/journal/2002/ 0423.htm

5. Definition and Selection of Competencies (DeSeCo). [Електроннии ресурс]. - Режим доступу: http:// www.oecd.org/fr/edu/apprendre-au-dela-de-l-ecole/ definitionandselectionofcompetenciesdeseco.htm

\section{REFERENCES}

1. Busel, V. T. (Ed.). (2005). Velykyi tlumachnyi slovnyk suchasnoi ukrainskoi movy [Great explanatory dictionary 
of modern Ukrainian language]. Kyiv, 1728 p. [in Ukrainian].

2. Dutkevych, T. V. (2016). Zahalna psykholohiia. Teoretychnyi kurs [General Psychology. Theoretical course]. Kyiv: Tsentr uchbovoi literatury, 388 p. [in Ukrainian].

3. Chernyshova, Ye. R., Huzii, N. V., \& Liakhotskyi, V. P. (Eds.). (2014). Terminolohichnyi slovnyk $z$ osnov pidhotovky naukovykh ta naukovo-pedaho-hichnykh kadriv pisliadyplomnoi pedahohichnoi osvity [Terminological dictionary on the basics of preparation of scientific and scientific-pedagogical staff of postgraduate pedagogical education]. Kyiv, $230 \mathrm{p}$. [in Ukrainian].

4. Khutorskyi, A. V. Kliuchevie kompetentsyy y obrazovatelnie standarti [Key competencies and educational standards]. [Electronic resource]. Available at: http://www.eidos.ru/journal/2002/0423.htm [in Russian].

5. Definition and Selection of Competencies (DeSeCo). [Electronic resource]. Available at: http://www.oecd.org/ $\mathrm{fr} / \mathrm{edu} / \mathrm{ap}$ prendre-a u-dela-de-1-ecole/ definitionandselectionofcompetenciesdeseco.htm [in English].

Стаття надійшла до редакції 03.12.2018

УДК 378.091.12.011.3-051:7(438)

DOI:

Юлія Колісник-Гуменюк, кандидат педагогічних наук старший викладач кафедри загальнотехнічних дисииплін і охорони праці відокремленого структурного підрозділу “Львівський навчально-науковий иентр професійно-технічної освіти” Національного педагогічного університету імені М.П. Драгоманова, м. Київ

\section{ПІДГОТОВКА ВИКЛАДАЧІВ ПРОФЕСІЙНО-ХУДОЖНЬОГО ПРОФІЛЮ У ПОЛЬЩІ}

Законодавче, навчально-методичне та матеріально-технічне забезпечення украӥнської освітньоі системи потребує суттєвого вдосконалення, тому вивчення та творче використання зарубіжного досвіду $\epsilon$ актуальним завданням педагогічних досліджень. У різних країнах, звичайно, існують певні відмінності в підходах до змісту й організаиії мистечької, педагогічної та професійно-художньої підготовки в закладах різного рівня. Прискіпливий огляд і узагальнення підходів до розвитку та вдосконалення художньо-педагогічноі освіти дають змогу виділити оригінальні риси національних систем і спільні світові тенденції. Розглянемо провідні тендениії розвитку вищої професійно-художньої освіти у Польщі, які важливі з огляду завдань модернізачії сучасної освіти Украӥни.

Ключові слова: вища освіта; фахівещь; художня освіта; коледж; художній профіль.

Jim. 5.

Yuliya Kolisnyk-Humenyuk, Ph.D.(Pedagogy), Senior Lecturer of the General Technical Disciplines and Labor Protection Department of Separate Structural Unit "Lviv Educational and Scientific Center of Vocational Education" National Mykhaylo Drahomanov Pedagogical University, Kyiv

\section{TRAINING OF LECTURERS OF PROFESSIONAL ARTISTIC PROFILE IN POLAND}

Legislative, teaching, methodological and logistical support of the Ukrainian educational system requires the significant improvement, therefore the study and creative use of foreign experience is an actual task of pedagogical research. In different countries, of course, there are some differences in approaches to the content and organization of artistic, pedagogical and professional-artistic training in institutions of different levels. A sophisticated review and synthesis of approaches to the development and improvement of artistic and pedagogical education make it possible to distinguish the original features of national systems and common world trends.

The work of both domestic and foreign researchers in the educational field of Great Britain, France, the USA, Japan and other countries with advanced educational systems shows, first of all, the priority of a person-oriented approach to learning, where the main role is given to the creativity of the student based on the ideas of free education of the person.

As the system analysis of foreign pedagogical education shows, the modern universities should provide conditions for the functioning of a variegated, multilevel system of education, the main advantage of which is that it is oriented to the prompt satisfaction of the needs of the educational system and the personal orientation of the students themselves. Western universities are mainly large educational and production complexes that combine educational and research institutes, colleges, faculties, departments, industry centers, problem laboratories, design and technology bureaus, which enable them to organize the flexible learning process, necessary for a broad interrelated and interdependent interdisciplinary training of a modern professional educator. There are a number of targeted projects on the basis of which they provide the opportunity to receive the specialists' diploma immediately after the completion of institutions of higher education or after a certain period of time, and even after many years. 